\title{
THE SUSTAINABLE IMPROVEMENT OF SOCIAL HOUSING STOCK IN ITALY: STRATEGIES OF INTERVENTION
}

\author{
S. BRUNORO \\ Department of Architecture, University of Ferrara, Ferrara, Italy.
}

\begin{abstract}
The paper summarizes the experience carried out by the Department of Architecture of the University of Ferrara in cooperation with ACER (Emilia Romagna public housing company) to assess the state of decay of a large part of social buildings between Ferrara and Reggio Emilia and to suggest architectural and technical interventions in order to meet new requirements both in terms of energy efficiency and architectural value. The main aim was to provide strategies of refurbishment mainly considering feasibility, real conditions and the cost of construction besides of the new energy efficiency standard. Examples of interventions focused on the use of renewable energies and sustainable technologies for building envelopes (e.g. external thermal insulation, greenhouses) are examined.

Keywords: Energy retrofit, renewable energies, social housing, sustainable technologies.
\end{abstract}

\section{INTRODUCTION}

Social buildings owned by public companies are very popular in the Italian suburbs. These large and highly populated living units clearly represent the main examples of energy consumption in the building sector. After the Second World War many reasons caused an intense building activity: the huge destruction of most cities, the migration of people from country to town, a significant population growth. These factors caused a big demand for dwellings, especially in the biggest cities with industrial centres. A fundamental role for the reconstruction was developed by Public Housing Institutes (IACP, INA-CASA, GESCAL, and ACER) by the promotion of several public and half-public building interventions. Most of the buildings in the suburban areas - generally multi-family housing blocks consisting of small apartments - were completed after 1950 by using low-cost technologies characterized by very poor quality, which contributes to the social decay of districts. With the new Italian energy efficiency regulation (D.Lgs 311/06), the new and existent buildings are forced to respect restricted standards for energy saving. This study is based on a range of examples developed during the course of Energetic control of buildings at the Faculty of Architecture of Ferrara and with the support of ACER (Emilia Romagna public housing company) of Ferrara and Reggio Emilia. An overview of the suburban housing stock based on the direct survey of about 100 buildings was done, in order to provide an energetic diagnosis of the existing buildings. Then, different scenarios of energy retrofit were developed and applied to a sample of 10 buildings, in order to carry out a 'step-by-step' strategy, starting from the most easy and cheap operations (e.g. replacement of boilers) up to the more expansive (e.g. photovoltaic panels). Performing envelopes and renewable energies are the most useful strategies to improve not only the energetic balance, but also the architectural value of these buildings. This approach can be helpful to public administrations to manage interventions by considering their incidence on the overall balance. The focus was therefore widened to comprise technical and architectural aspects as well, and to give indications on the feasibility of some interventions comparing to others [1]. 
2 SOCIAL HOUSING STOCK IN EMILIA ROMAGNA REGION. 10 PILOT PROJECTS The most part of the Italian post-war estate was built between 1950 and 1970 years and is characterized by the use of multi-storey building blocks, which were considered the most suitable for a multitude of needs and adaptable to each situation.

Emilia Romagna region confirms this tendency, and can rate a big number of suburban areas that are very lacking both in terms of energy efficiency that in terms of architectural and technical value.

About 100 buildings between Ferrara and Reggio Emilia territory, owned by Acer housing Company, were examined during the course of Energetic control of buildings at the Department of Architecture (Fig. 1, Table 1).

The aim of the work was to investigate the main causes of energy fault and give an energy diagnosis that is the basis for the evaluation of possible refurbishment actions in order to optimize cost and benefits. For an easier data comparison and synthesis it was decided to consider for this paper a sample of 10 buildings. Case studies were selected by considering the following criteria:

- owned by Acer Company, that can provide for technical drawings (dimensional survey not necessary);

- to provide a good range of dimensions, by considering both extended buildings (for energy efficiency decree 311/06 over 1000 square meters) than small buildings;

- to have an overview on the main diffuse technologies, considering both load bearing walls than prefab panels than pillar-beams technologies. This should mean to investigate different type of walls, so different type of $U$ value and consequently different incidence on the refurbishment action;

- to consider both autonomous than centralized installations.

This selection can simplify the procedure and at the same time offer a widespread range of technical systems, dimensions and technologies.

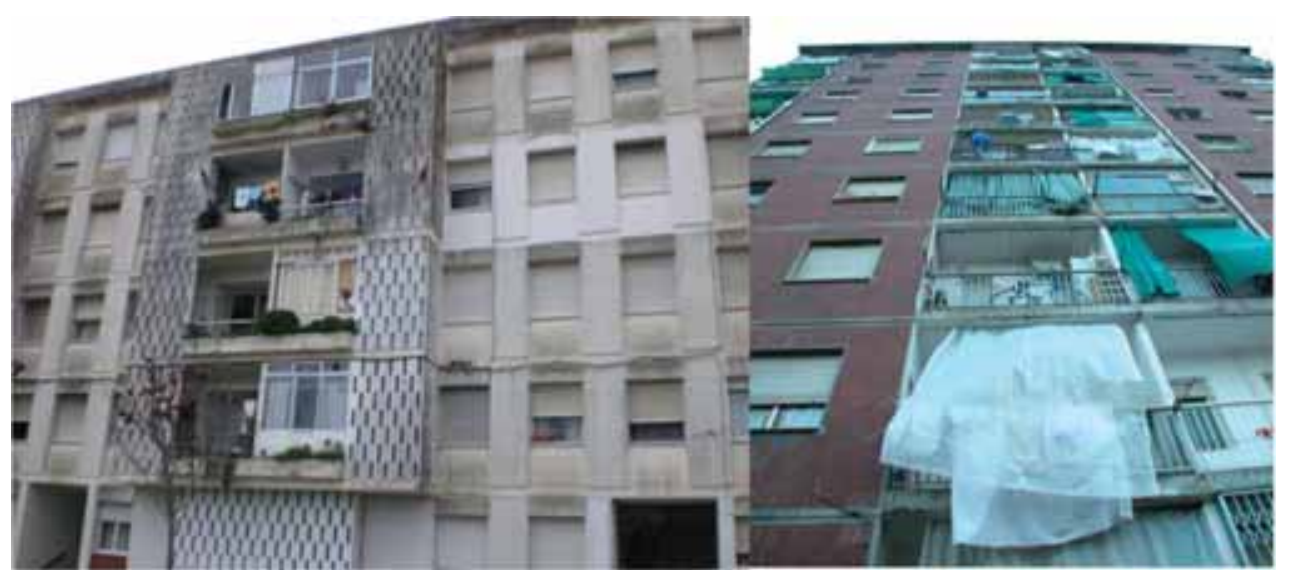

Figure 1: Profile of ACER multi storey building blocks in Emilia Romagna region (Italy). 
The main building technologies can be summarized in three main types [2]:

1. Bearing structure of steel reinforced concrete beams and pillars of in situ concrete. To this skeleton, façades and partition walls are added, using mostly hollow brick blocks;

2. Load bearing brick walls;

3. Industrialized building technologies that, starting from the sixties, were imported from beyond the Alps and briefly diffused, such as tunnel formworks, pre cast large panels and three-dimensional elements.

Floors are usually reinforced concrete slabs, but pre-strengthened beams with filling blocks are also commonly used.

Facades can be bearing brick wall, perforated brickwork or prefabricated concrete panels. Perforated brick walls are single or, rarely, double layer with $4 \mathrm{~cm}$ air cavity where in a few cases thermal insulation is present. Dimensions ranges between 27 (single) to 32 (double) $\mathrm{cm}$.

External and internal layer is, for the most part, plaster. Panels are single or multi layer and generally finished by gray smooth concrete. The most common materials used for window frames are wood and aluminium, rarely plastic. As the most part of the housing stock was built before the first petrol crisis in 1973 and the consequent law n. 373/1976, it has single glazed window panes.

Both flat and pitched roofs are used. The structure is generally the same used for the floors: trestle floor beams and hollow floor blocks or prefabricated concrete panels. Flat roofs are usually finished with two layers of asphalt paper and a $4 \mathrm{~cm}$ thick layer of gravel. Slope roofs are finished with roof tiles.

Poor physical and technical performance of the buildings cause many problems and may even cause serious health risks for the tenants. The problems are mainly related to poor envelopes and are of various origin: lack of thermal insulation (only in few cases there insulation panels are present in the wall cavity), moisture problems that are mainly connected with humidity, condensation on thermal bridges, surface infiltrations, moisture and attack by moulds.

Gas methane is the most used fuel for heating. Centralized boilers, in common boiler rooms, are present in almost all the buildings examined. The remaining buildings have single boilers for each apartment. District heating is present in three case studies.

Environmental impact during the management phases of the building is in particular related to heating systems. During the second post-war period the principle of managerial autonomy wasn't adverted because of the disposition of low-cost energy, so most of the buildings were realized with central heating with no possibility of regulation. This is cause of low thermal efficiency that means maximum consumption and maximum pollution emissions in atmosphere and thermal discomfort for the residents.

\section{ASSESSMENT METHODODOLOGY}

The energetic performance of the buildings was estimated using a specific software called MC11300 (Masterclima) that evaluates the energetic performance in winter season (heating and hot water supply) in compliance with Law 311/06 that regulates energy efficiency in Italy.

This software operates in a simplified steady state regime by following the calculation method defined by technical regulation (UNI TS 11300 Parts 1 and 2) that calculates the global energy performance (EPi) as the sum of primary energy for heating and hot water supply, in kWh per square meter per year.

The EPi calculation considers a multitude of factors that influences the energy performance of a building: surface and volume (shape/dimension of the building), orientation and solar gains, walls, windows, floors and roof materials transmission ( $U$ value), type of fuel and plants. 
Table 1: Basic data related to a sample of 10 suburban multi storey building blocks in Ferrara, Reggio Emilia and Bologna (Italy) [1].

\begin{tabular}{|c|c|c|c|c|c|}
\hline Building & Walls & Windows & Roof & Plants & $\begin{array}{l}\text { Energy Per } \\
\text { Formance } \\
\text { (Kwh/M } \mathrm{M}^{2} / \text { Year) }\end{array}$ \\
\hline $\begin{array}{l}\text { Via Pietro } \\
\text { Lana } \\
\text { Ferrara }\end{array}$ & $\begin{array}{l}\text { Internal plaster, } \\
\text { hollow brick } \\
\text { blocks and } \\
\text { exposed bricks } \\
26 \mathrm{~cm} \\
\mathrm{U}=1.36 \\
\mathrm{~W} / \mathrm{mq} \mathrm{K}\end{array}$ & $\begin{array}{l}\text { Wood frame } \\
\text { with single } \\
\text { panes glass } \\
\mathrm{U}=4.8 \\
\mathrm{~W} / \mathrm{mq} \mathrm{K}\end{array}$ & $\begin{array}{l}\text { Concrete slab } \\
\text { with tiles. No } \\
\text { insulation. }\end{array}$ & $\begin{array}{l}\text { District } \\
\text { heating }\end{array}$ & $\begin{array}{l}272 \mathrm{Kwh} \mathrm{m}^{2} \mathrm{a} \\
\text { Square meters } \\
1850\end{array}$ \\
\hline $\begin{array}{l}\text { Via } \\
\text { Grosoli - } \\
\text { Gatti Casazza } \\
\text { Ferrara }\end{array}$ & $\begin{array}{l}\text { Exposed brick } \\
\text { wall } 13.5 \mathrm{~cm} \\
\mathrm{U}=1.82 \\
\mathrm{~W} / \mathrm{mq} \mathrm{K}\end{array}$ & $\begin{array}{l}\text { Aluminum } \\
\text { frame with } \\
\text { single glass }\end{array}$ & $\begin{array}{l}\text { Slope } \\
\text { roof with } \\
\text { roof tiles. No } \\
\text { insulation. }\end{array}$ & $\begin{array}{l}\text { Single } \\
\text { boiler one for } \\
\text { apartment }\end{array}$ & $\begin{array}{l}320 \mathrm{Kwh} \mathrm{m} \mathrm{m}^{2} \mathrm{a} \\
\text { Square meters } \\
250\end{array}$ \\
\hline $\begin{array}{l}\text { Via } \\
\text { Ungarelli - } \\
\text { Foro Boario } \\
\text { Ferrara }\end{array}$ & $\begin{array}{l}\text { Brick wall + } \\
3 \mathrm{~cm} \text { etics }\end{array}$ & $\begin{array}{l}\text { Plastic frame } \\
\text { with single } \\
\text { glass }\end{array}$ & $\begin{array}{l}\text { Flat roof with } \\
\text { asphalt paper } \\
\text { and gravel. }\end{array}$ & $\begin{array}{l}\text { Single } \\
\text { boiler one for } \\
\text { apartment }\end{array}$ & $\begin{array}{l}280 \mathrm{Kwh} \mathrm{m}^{2} \mathrm{a} \\
\text { Square meters } \\
260\end{array}$ \\
\hline $\begin{array}{l}\text { Via Medini } \\
\text { Ferrara }\end{array}$ & $\begin{array}{l}\text { Two layers } \\
\text { hollow brick } \\
\text { blocks, plaster } \\
\text { finishing }\end{array}$ & $\begin{array}{l}\text { Aluminum } \\
\text { frame with } \\
\text { single glass }\end{array}$ & $\begin{array}{l}\text { Slope roof } \\
\text { with metallic } \\
\text { covering. No } \\
\text { Insulation }\end{array}$ & $\begin{array}{l}\text { Centralized } \\
\text { boiler - air } \\
\text { heater }\end{array}$ & $\begin{array}{l}215 \mathrm{Kwh} \mathrm{m} \mathrm{m}^{2} \mathrm{a} \\
\text { Square meters } \\
600\end{array}$ \\
\hline $\begin{array}{l}\text { Via Barlaam } \\
\text { Ferrara }\end{array}$ & $\begin{array}{l}\text { Hollow brick } \\
\text { blocks and } \\
\text { exposed } \\
\text { bricks } 26 \mathrm{~cm} \\
\mathrm{U}=1.36 \\
\mathrm{~W} / \mathrm{mq} \mathrm{K}\end{array}$ & $\begin{array}{l}\text { Wooden } \\
\text { frame with } \\
\text { single panes } \\
\text { glass } \\
\mathrm{U}=3.7 \\
\text { W/mq K }\end{array}$ & $\begin{array}{l}\text { Terrace roof. } \\
\text { Concrete } \\
\text { slabs with } \\
\text { ceramic floor. } \\
\mathrm{U}=1.34 \\
\mathrm{~W} / \mathrm{mq} \mathrm{K}\end{array}$ & $\begin{array}{l}\text { District } \\
\text { heating }\end{array}$ & $\begin{array}{l}187 \mathrm{Kwh} \mathrm{m} \mathrm{m}^{2} \mathrm{a} \\
\text { Square meters } \\
4692\end{array}$ \\
\hline $\begin{array}{l}\text { Via } \\
\text { Monti-Foro } \\
\text { Boario } \\
\text { Ferrara }\end{array}$ & $\begin{array}{l}\text { Hollw brick } \\
\text { blocks } 30 \mathrm{~cm} \\
\mathrm{U}=0.97 \\
\mathrm{~W} / \mathrm{mq} \mathrm{K}\end{array}$ & $\begin{array}{l}\text { Wooden } \\
\text { frame with } \\
\text { single panes } \\
\text { glass } \\
\mathrm{U}=3.7 \\
\mathrm{~W} / \mathrm{mq} \mathrm{K}\end{array}$ & $\begin{array}{l}\text { Slope roof } \\
\text { with wooden } \\
\text { frame } \\
\text { and tiles } \\
\mathrm{U}=1.90 \\
\mathrm{~W} / \mathrm{mq} \mathrm{K}\end{array}$ & $\begin{array}{l}\text { Single Boiler } \\
\text { - one for } \\
\text { apartment }\end{array}$ & $\begin{array}{l}326 \mathrm{Kwh} \mathrm{m} \mathrm{m}^{2} \mathrm{a} \\
\text { Square meters } \\
415\end{array}$ \\
\hline $\begin{array}{l}\text { Barca } \\
\text { Building } \\
\text { Bologna }\end{array}$ & $\begin{array}{l}\text { Hollow brick } \\
\text { blocks and } \\
\text { exposed } \\
\text { bricks } 30 \mathrm{~cm} \\
\mathrm{U}=1.26 \\
\mathrm{~W} / \mathrm{mq} \mathrm{K}\end{array}$ & $\begin{array}{l}\text { Plastic frames } \\
\text { with double } \\
\text { layer glass } \\
\text { panes } \\
\mathrm{U}=2.2 \\
\text { W/mq K }\end{array}$ & $\begin{array}{l}4 \text { pitched } \\
\text { roof. Concrete } \\
\text { slabs with } \\
\text { bitumen and } \\
\text { metallic coat. } \\
\mathrm{U}=2.26 \\
\mathrm{~W} / \mathrm{mq} \mathrm{K}\end{array}$ & $\begin{array}{l}\text { District } \\
\text { heating }\end{array}$ & $\begin{array}{l}273 \mathrm{Kwh} \mathrm{m}^{2} \mathrm{a} \\
\text { Square meters } \\
3372\end{array}$ \\
\hline
\end{tabular}


Table 1: Continued

\begin{tabular}{|c|c|c|c|c|c|}
\hline Building & Walls & Windows & Roof & Plants & $\begin{array}{l}\text { Energy Per } \\
\text { Formance } \\
\left(\text { Kwh/M } \mathrm{M}^{2} / \text { Year }\right)\end{array}$ \\
\hline $\begin{array}{l}\text { Via due canali } \\
5 \text { Reggio } \\
\text { Emilia }\end{array}$ & $\begin{array}{l}\text { Hollow brick } \\
\text { blocks } 28 \mathrm{~cm} \\
\mathrm{U}=1.4 \\
\mathrm{~W} / \mathrm{mq} \mathrm{K}\end{array}$ & $\begin{array}{l}\text { Wooden } \\
\text { frames with } \\
\text { single layer } \\
\text { panes } \\
\mathrm{U}=3.2 \\
\text { W/mq K }\end{array}$ & $\begin{array}{l}\text { Slope roof, } \\
\text { hollow } \\
\text { brick tiles } \\
\text { with concrete } \\
\text { completion. } \\
\mathrm{U}=0.95 \\
\text { W/mqK }\end{array}$ & $\begin{array}{l}\text { Centralized } \\
\text { boiler in } \\
\text { separate boiler } \\
\text { room }\end{array}$ & $\begin{array}{l}315 \mathrm{Kwh} \mathrm{m} \mathrm{m}^{2} \mathrm{a} \\
\text { Square meters } \\
500\end{array}$ \\
\hline $\begin{array}{l}\text { Via Mara- } \\
\text { motti } \\
25 \text { Reggio } \\
\text { Emilia }\end{array}$ & $\begin{array}{l}\text { Concrete } \\
\text { prefab panels } \\
\text { with insulating } \\
\text { layer } 24 \mathrm{~cm} \\
\mathrm{U}=0.67 \\
\mathrm{~W} / \mathrm{mq} \mathrm{K}\end{array}$ & $\begin{array}{l}\text { Aluminium } \\
\text { frames with } \\
\text { double glass } \\
\mathrm{U}=2.9 \\
\mathrm{~W} / \mathrm{mq} \mathrm{K}\end{array}$ & $\begin{array}{l}\text { Flat concrete } \\
\text { slab with } \\
\text { insulating } \\
\text { layer } \mathrm{cm} 25 \\
\mathrm{U}=0.40 \\
\mathrm{~W} / \mathrm{mq} \mathrm{K}\end{array}$ & $\begin{array}{l}\text { Centralized } \\
\text { boiler in } \\
\text { separate boiler } \\
\text { room }\end{array}$ & $\begin{array}{l}129 \mathrm{Kwh} \mathrm{m}{ }^{2} \mathrm{a} \\
\text { Square meters } \\
850\end{array}$ \\
\hline $\begin{array}{l}\text { Tito Minniti } \\
\text { Ferrara }\end{array}$ & $\begin{array}{l}\text { Brick wall with } \\
\text { plaster } 28 \mathrm{~cm} \\
\mathrm{U}=1.45 \\
\mathrm{~W} / \mathrm{mq} \mathrm{K}\end{array}$ & $\begin{array}{l}\text { Wooden } \\
\text { frames with } \\
\text { single glass } \\
\mathrm{U}=3.9 \\
\mathrm{~W} / \mathrm{mq} \mathrm{K}\end{array}$ & $\begin{array}{l}\text { Slope and flat } \\
\text { roof, concrete } \\
\text { slab with roof } \\
\text { tiles }\end{array}$ & $\begin{array}{l}\text { Single } \\
\text { Boiler one for } \\
\text { apartment }\end{array}$ & $\begin{array}{l}186 \mathrm{Kwh} \mathrm{m} \mathrm{m}^{2} \mathrm{a} \\
\text { Square meters } \\
2238.93\end{array}$ \\
\hline
\end{tabular}

This methodology allows to classify a building according to its global energy consumption by using an 'energy class' that expresses its energy performance (EPi classes). The values range from the 'G' class (worst class) to the 'A' class (best class).

The in depth energetic diagnosis highlighted that the above mentioned building stock is very lacking as for the energy efficiency (all the building were classified in G class) as for the architectural quality (bad state of conservation, decay of plaster and windows).

The payback period for the financial investment of the refurbishment actions was calculated by using as simplified method that refers to the period of time required for the return on an investment to 'repay' the sum of the original investment. Payback period intuitively measures how long something takes to 'pay for itself' and it is widely used because of its ease of use despite the recognized limitations described below. Each retrofit action was calculate by using the energy software Masterclima and compared to the current energy performance, to obtain how much $\mathrm{kWh}$ per square meter per year can be saved by using that solution in each building. By considering that $10.78 \mathrm{kWh}$ corresponds to $1 \mathrm{mc}$ of methane, the cubic meters of methane saved by means of a specific refurbishment action were calculated.

Finally, considering the current methane cost of 0.830 Euro/mc, the Euro per year saved due to the refurbishment action was estimated. The time value of money is not taken into account. This value was compared with the initial investment cost for the energy retrofit intervention to obtain the number of years needed to compensate the initial investment through positive cash flows. In practice, it is the first date on which a sign reversal occurs in cash balances. 
By using this simplified procedure criterion, an investment is much more preferable as the period of refund is smaller. The method, however, has limitations because it does not take into account the trend of cash flow after recovery of the initial. Anyway this easy methodology is commonly used to evaluate the period over which the energy savings of a project equal the amount of energy expended since project inception and to compare similar investments in this field.

\section{ENERGY RETROFIT ACTIONS: FROM A 'BEST PRICE' TO 'BEST PRACTICE' STRATEGY}

Different refurbishment purposes were considered, taking in account a progressive modus operandi in terms of:

- Feasibility (e.g. occupant diseases during building site);

- Initial investment (necessity to reduce refurbishment costs due to the public ownership);

- Improving energy efficiency and energy saving benefits in the long period;

- Increasing architectural value.

By considering these variables, a 'best price to best practice' strategy was developed. This means progressive interventions, starting from the most economic solution to a best practice solution, in which a complete refurbishment is considered.

Should the more expensive solution be the most convenient in term of initial investment/payback? Some different scenarios have been examined in order to answer to this question. The aim of the study was to give indications that can be helpful to designers and public administration to guide their investments on refurbishment intervention to maximize costs and benefits.

Main refurbishment actions from the minimum intervention to the total refurbishment are below examined.

\subsection{Heat generators substitution}

At a first stage, the hypothesis of replacing of old heat generators with more efficient ones was considered as the minimum intervention. In the most cases heat generators were very old, and do not fulfill energy efficiency new standards, so it was considered to make a substitution both in the case of autonomous boilers (one for each apartment) than in case of centralized heat generator (Fig. 2).

The strategy considers only essential modifications of the heating system network, that is the minimum threshold of feasibility without interfere with normal inhabitants' activities. It was considered to install condensation boilers: they can maximize energy performance due to their very high performance (about $95-98 \%$ of efficiency in comparison to $80-85 \%$ for a traditional boiler). These boilers allow about 25-30\% of energy saving with traditional heaters, but they express their maximum performance with low temperature installation (e.g. floor heater). Also in the case of centralized heating - in a common boiler room - the substitution with high efficiency boilers was supposed.

By considering the table below, it can be said that the incidence of boiler substitution causes an energy saving of about $15-20 \%$ of the global energy balance per building. This corresponds to the improvement of the energetic performance of about $70 \mathrm{kWh} / \mathrm{m}^{2} /$ year (in the most cases buildings remain in the same class, mostly $\mathrm{G}$ and $\mathrm{F}$ class). This kind of intervention can be done with an affordable initial cost, with a payback period of not more of 5 years (Table 2). 
Table 2: Heat generator substitution: Energy performance, money saved and payback period [1].

\begin{tabular}{|c|c|c|c|c|c|c|c|c|c|c|}
\hline & $\begin{array}{l}\text { Pietro } \\
\text { Lana } \\
\text { Ferrara }\end{array}$ & $\begin{array}{l}\text { Grosoli } \\
\text { Ferrara }\end{array}$ & $\begin{array}{l}\text { Ungarelli } \\
\text { Ferrara }\end{array}$ & $\begin{array}{l}\text { Medini } \\
\text { Ferrara }\end{array}$ & $\begin{array}{l}\text { Barlaam } \\
\text { Ferrara }\end{array}$ & $\begin{array}{l}\text { Monti } \\
\text { Ferrara }\end{array}$ & $\begin{array}{l}\text { Tito } \\
\text { Minniti } \\
\text { Ferrara }\end{array}$ & $\begin{array}{l}\text { Due } \\
\text { Canali } \\
\text { Reggio } \\
\text { Emilia }\end{array}$ & $\begin{array}{l}\text { Maramotti } \\
\text { Reggio } \\
\text { Emilia }\end{array}$ & $\begin{array}{l}\text { Barca } \\
\text { Bologna }\end{array}$ \\
\hline $\begin{array}{l}\mathrm{kWh} / \mathrm{m}^{2} \\
\text { year } \\
\text { before }\end{array}$ & 272 & 320 & 380 & 215 & 187 & 326 & 241 & 315 & 129 & 273 \\
\hline $\begin{array}{l}\mathrm{kWh} / \mathrm{m}^{2} \\
\text { year } \\
\text { after }\end{array}$ & 192 & 240 & 300 & 135 & 110 & 251 & 161 & 235 & 63 & 193 \\
\hline $\begin{array}{l}\text { Mc methane/ } \\
\text { year saved }\end{array}$ & 14.800 & 2.000 & 2.080 & 4.250 & 36.000 & 3.608 & 17.904 & 4.000 & 6.800 & 25.290 \\
\hline $\begin{array}{l}\text { Euro/year } \\
\text { saved }\end{array}$ & 12.000 & 1.660 & 1.800 & 3.735 & 29.000 & 3.000 & 14.860 & 3.200 & 5.644 & 20.900 \\
\hline $\begin{array}{l}\text { Payback } \\
\text { period (year) }\end{array}$ & 4 & 5 & 5 & 4 & 2 & 5 & 2 & 4 & 2 & 2 \\
\hline
\end{tabular}
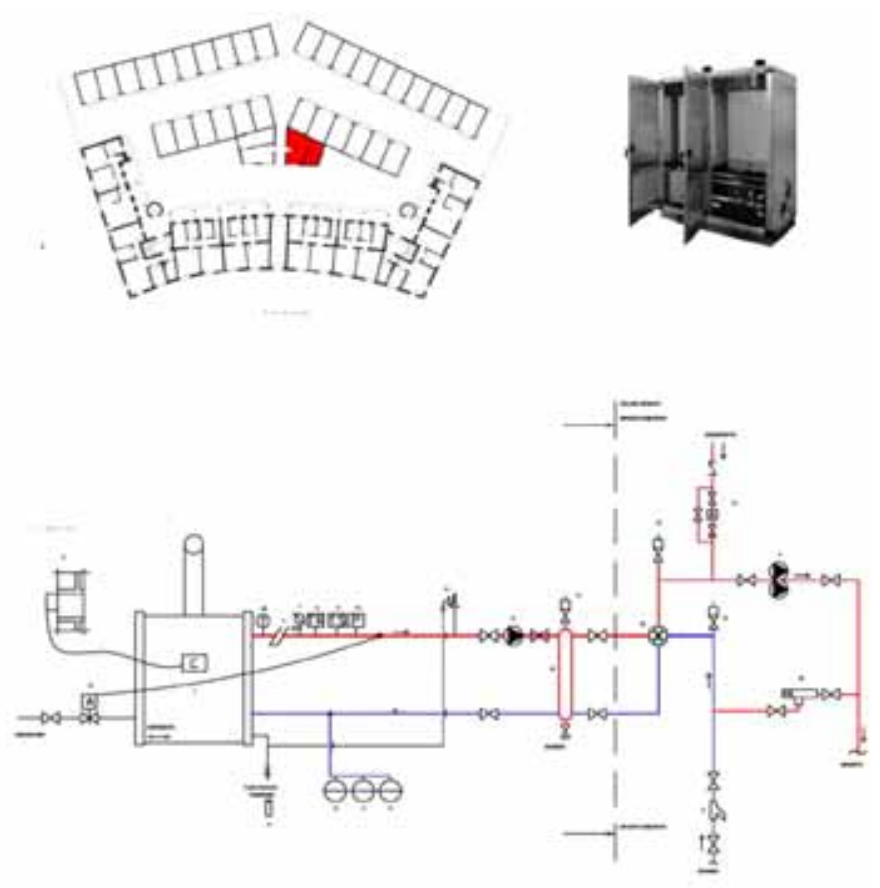

Figure 2: Design for a new centralized heating system located in a technical room near the garages in Tito Minniti building. The condensation boiler is type BAXI, with a power of $300 \mathrm{~kW}$ and nominal efficiency of $105.2 \%$. 


\subsection{Replacing of windows}

The first intervention in order to improve energy efficiency of the envelope is the replacing of existing windows. This kind of solution should be done in the most cases without confining the occupants in other apartments, and with limited disease for the inhabitants. The hypothesis of refurbishment considered LOW - E double layer glass panes with $\operatorname{argon}$ gas $\left(\mathrm{U}=1.3 \mathrm{~W} / \mathrm{m}^{2} \mathrm{~K}\right)$. The special wooden frame with polystyrene is optimum for the thermal bridge reduction. Anyway, a partial intervention on the envelope may create some problems that have necessarily taken in account. In the most cases, opaque surface is so extended and its thermal transmittance is so lacking that the incidence of windows in the overall façade is not remarkable, moreover improving windows performance without considering walls insulation may reinforce the thermal bridges between the joint window frame-wall $[2,3]$.

An in depth evaluation shows how the incidence of replacing windows on the overall energetic performance can be of about $20 \%$. An investment of about 300 Euro for windows, can improve energy performance of about $70 \mathrm{kWh} / \mathrm{m}^{2} /$ year (in some cases the energy balance can make a jump of one class) (Fig. 3). By considering the initial cost (that can range from 24.000 to 40.000 , depending on the case study), payback period can range from 6 to 11 years. Cubic meters of methane saved and Euro/year saved becomes remarkable in the case of buildings with extended fronts with a large number of windows. Although, in these cases, the cost of the intervention grows. By considering cost-benefits balance, it should be said that an improvement of the whole envelope should be desirable, as initial costs should be amortized with a better energy performance (Table 3 ).

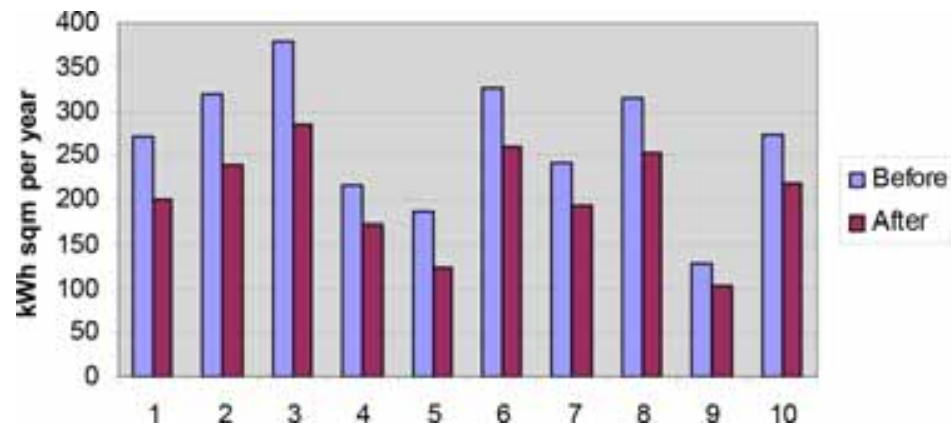

Figure 3: Replacing of windows. Energy performance of buildings before and after the intervention.

Table 3: Replacing of windows: methane saved, money saved and payback period [1].

\begin{tabular}{|c|c|c|c|c|c|c|c|c|c|c|}
\hline & \multirow[b]{2}{*}{ Pietro } & \multirow[b]{3}{*}{ Grosoli } & \multirow[b]{3}{*}{ Ungarelli } & \multirow[b]{3}{*}{ Medini } & \multirow[b]{3}{*}{ Barlaam } & \multirow[b]{3}{*}{ Monti } & \multirow{3}{*}{$\begin{array}{l}\text { Tito } \\
\text { Minniti }\end{array}$} & \multicolumn{2}{|l|}{ Due } & \multirow[b]{3}{*}{ Barca } \\
\hline & & & & & & & & Canali & Maramotti & \\
\hline & Lana & & & & & & & Reggio & Reggio & \\
\hline & Ferrara & Ferrara & Ferrara & Ferrara & Ferrara & Ferrara & Ferrara & Emilia & Emilia & Bologna \\
\hline $\begin{array}{l}\text { Mc methane/ } \\
\text { year saved }\end{array}$ & 12000 & 2000 & 2500 & 2580 & 19700 & 2739 & 10970 & 3150 & 2210 & 18500 \\
\hline $\begin{array}{l}\text { Euro/year } \\
\text { saved }\end{array}$ & 10000 & 1660 & 2050 & 2100 & 16300 & 2273 & 9100 & 2164 & 1834 & 15390 \\
\hline $\begin{array}{l}\text { Payback } \\
\text { period (year) }\end{array}$ & 7 & 10 & 11 & 8 & 7 & 10 & 9 & 8 & 9 & 6 \\
\hline
\end{tabular}




\subsection{External thermal insulation coating}

One of the most suitable solution for improving thermal insulation in walls is External Thermal Insulation Coating (ETICS), that consists of an external covering with insulating panels, fixed to the existing surfaces through wedges and binders, then armed with special nets and completed with a thin layer of plaster $[3,4]$. The application of ETICS became in the last ten years a popular measure to improve the energy performance and the weather resistance of façades in the building stock. Even if it is frequently supposed that the small thickness of the exterior plaster and a smooth insulation material as substrate are possible causes for damage from mechanical impact, many experiences can demonstrate that the costs and frequency of maintenance for ETICS are less than those of traditional wall structures [2, 5].

Energy regulation standards in Emilia Romagna region for walls is expressed with a maximum thermal transmittance (U value) of $0.34 \mathrm{~W} / \mathrm{m}^{2} \mathrm{~K}$. In the most cases, initial wall transmittance was higher that $1.2 \mathrm{~W} / \mathrm{m}^{2} \mathrm{~K}$ : this means that $12 \mathrm{~cm}$ of extruded polystyrene insulation layer was considered (Fig. 4).

Improving building envelope by adding a thermal insulation layer can be considered as a very good result for global energy efficiency. In the case of minimum standard requirements (Emilia Romagna regulation standard) global thermal transmittance of walls has been reduced of one third.

An average cost for the complete realization of ETICS can range from 70 to $90 \mathrm{Euro} / \mathrm{m}^{2}$. The reduction of fuel consumption in the case studies examined is remarkable. An average of $120 \mathrm{kWh} \mathrm{m}$ /year were saved, with a jump from G-F class to D class (Fig. 5). Cubic meters of gas methane saved depends on the building surface: in some buildings value can reach $18.000 \mathrm{~m}^{3}$, for an average money saving of about 15.000 Euro/year. Payback period is, in the most cases 10 years (Table 4$)$.

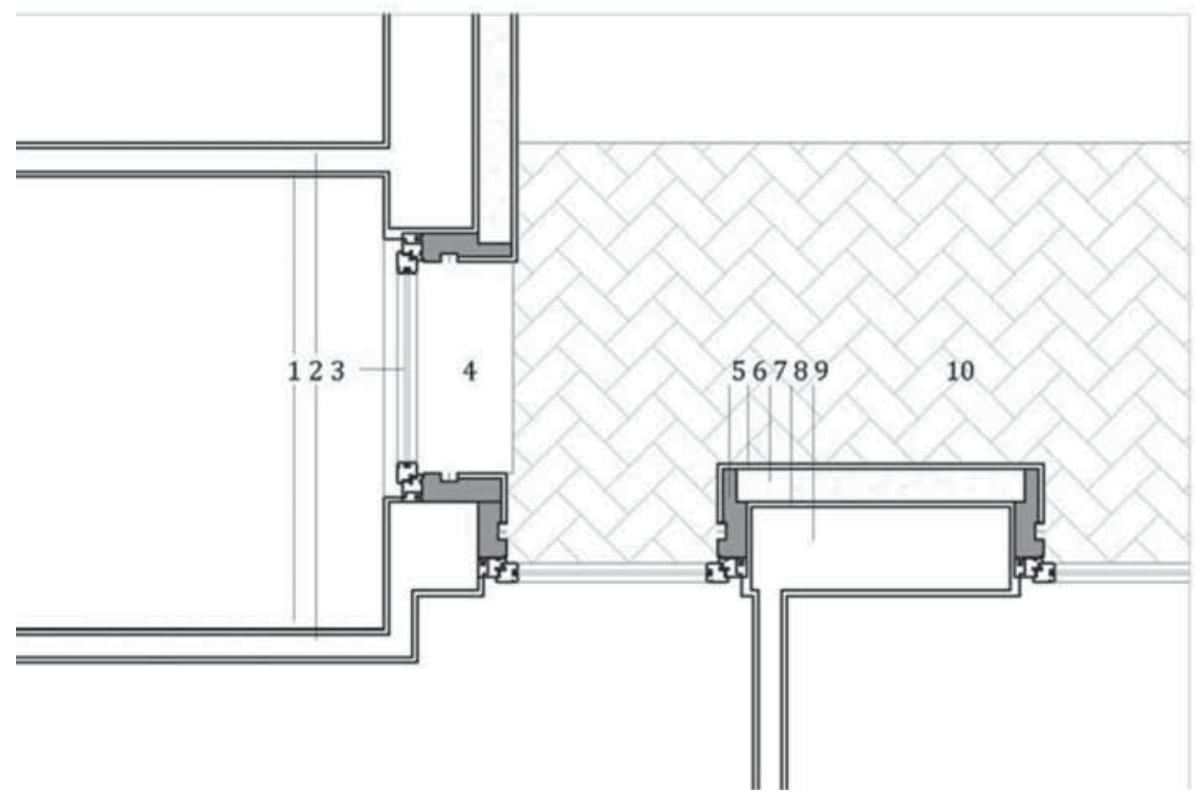

Figure 4: Adding external thermal insulation (12 $\mathrm{cm}$ of extruded polystyrene). Horizontal section and thermal bridges analysis in correspondence of the windows. (1) Plaster (2) Wall (3) Window (4) Windowsill (5) Special insulation (ISO) block (6) External plaster $(1 \mathrm{~cm})(7)$ ETICS $(12 \mathrm{~cm})(8)$ Levelling thin plaster (9) Existing brick wall $(25 \mathrm{~cm})$. 


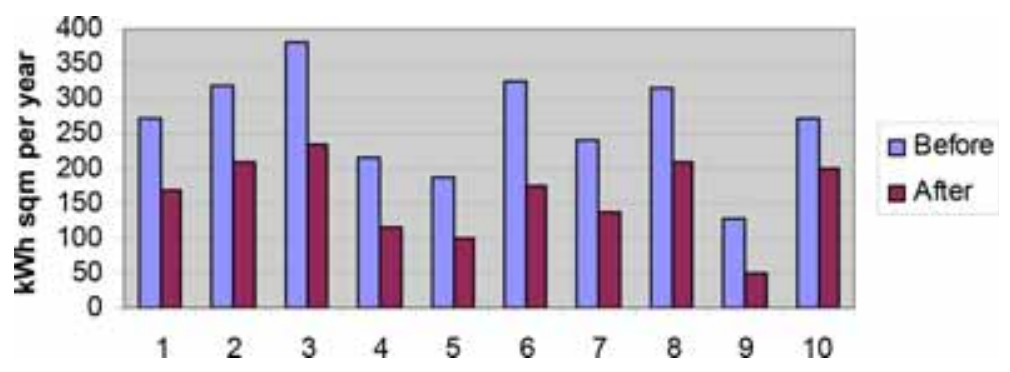

Figure 5: Adding ETICS. Energy performance of buildings before and after the intervention.

Table 4: Adding ETICS: Methane saved, money saved and payback period [1].

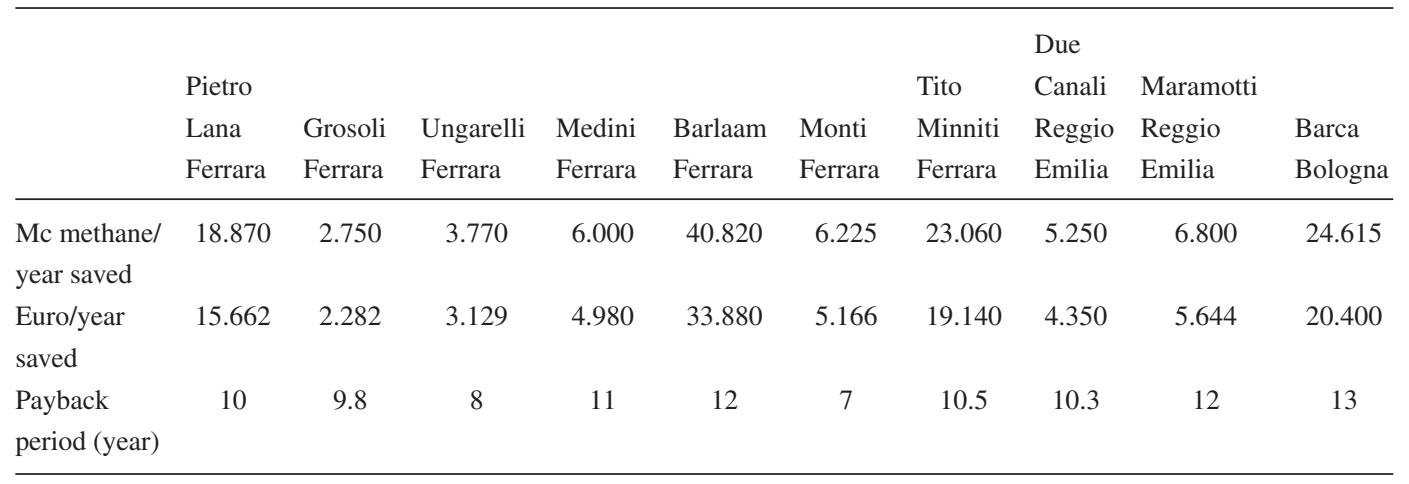

\subsection{Renewable energies: Solar collectors and photovoltaic systems}

In some of the case studies, the possibility to integrate the use of renewable energies was considered, by doing the following preanalysis:

- Assessing the suitability of the building (e.g. roof/façade/balcony) for photovoltaic (PV) solar installation;

- Site survey: orientation, latitude, yearly hours/sun, shadow range for PV best efficiency; (Fig. 6)

- Solar collectors and PV installation design (square meters, position, angle);

- Estimate of yearly energy production;

- Initial investment cost and energy saving cost for payback period evaluation.

Solar collectors (water heating systems) can offer a very good opportunity for heating hot water with the use of thermal radiation. Flat-plate and evacuated-tube solar collectors are commonly used to collect heat for space heating, domestic hot water or cooling with an absorption chiller. The main use of this technology is in residential buildings where the demand for hot water has a large impact on energy bills. This can represent a valid alternative to reduce overall energy balance of a building that is composed by heating system and domestic hot water (as calculated according to Italian regulation for winter season output). Solar collectors are mainly installed on roof, as their dark architectural aspect (due to the absorber area), makes very difficult the façade application, differently from PV panels that can be also transparent. 

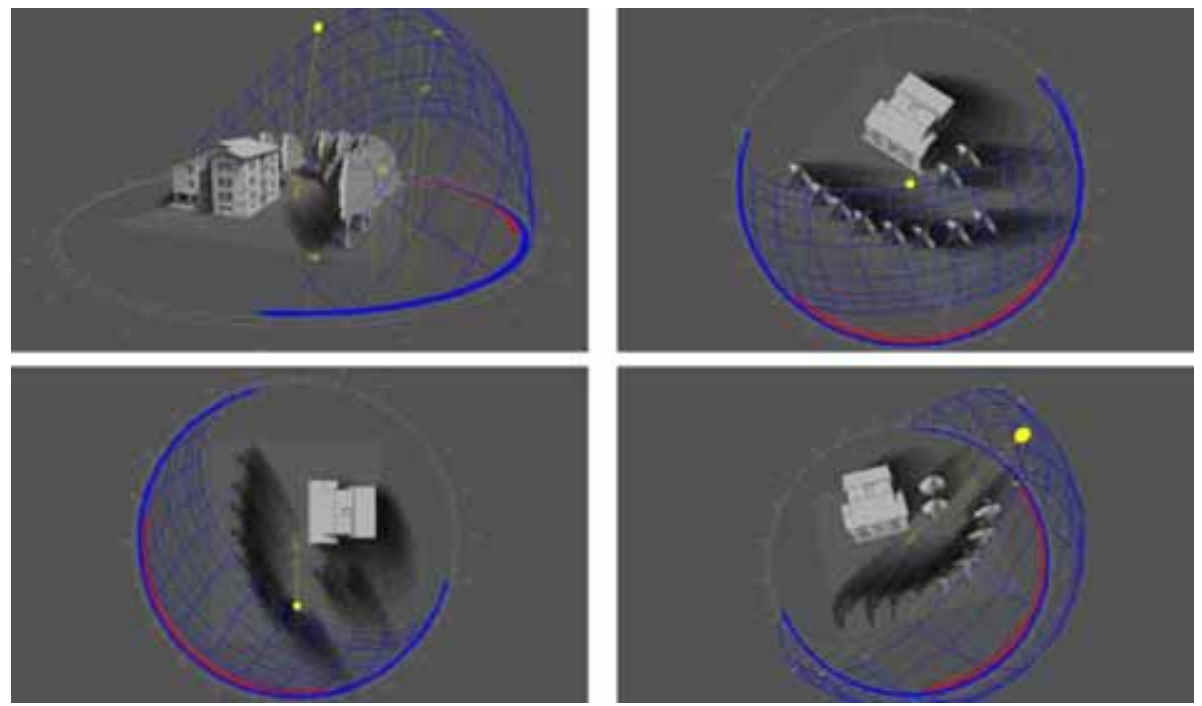

Figure 6: Shadow range and maximum solar radiation analysis (21st June) for solar collectors and photovoltaic panels installation project in via Ungarelli building.

Solar water heating systems are designed to deliver hot water for most of the year. However, in winter there sometimes may not be sufficient solar heat gain to deliver sufficient hot water. In this case a gas or electric booster is normally used to heat the water. Electric booster may be powered by electricity from PV panels, so renewable energy must be total [6].

The use of solar collectors can produce an energy saving of about 30-40\% of the total energy balance. This can mean a jump of one energetic class in more or less all the buildings examined. By considering that domestic hot water is one of the most crucial factors in the energy efficiency balance calculation in winter season (besides of envelope characteristics and thermal heating) it can be said that this kind of intervention has to be consider as the driving force for energy efficiency achievement, as well as improving envelope transmittance.

Moreover, the production of electricity by using a PV installation was evaluated. A PV system uses one or more panels to convert sunlight into electricity. It consists of multiple components, including the PV modules, mechanical and electrical connections and mountings and means of regulating or modifying the electrical output.

In all the examined case studies it can be said that the use of PV system installation should be convenient, as even if initial costs may be very high, energy production due to the best conditions of orientation/installation assure a payback period not over to 20 years, that is the maximum threshold of convenience for PV installation [4, 7].

In particular, the evaluation takes in account a current opportunity provided by law that is called 'Conto Energia' that is a program of incentives for electricity from solar energy using PV systems permanently connected to the electric grid. This financial systems provides for a monthly rate for each $\mathrm{kW}$ of electricity produced by the PV installation, that are grid connected. With the fifth Conto Energia, the installation can repay $0.237 € / \mathrm{kWh}$ for electricity launched in the electricity grid and $0.335 € / \mathrm{kWh}$ for the self-sustainment (energy used by the building). By means of the incentives, the payback period for a PV installation is not higher than 11-12 years (Table 5). 
Table 5: Photovoltaic system installation, energy performance, money saved and payback period.

\begin{tabular}{|c|c|c|c|c|c|c|c|c|c|c|}
\hline & $\begin{array}{l}\text { Pietro } \\
\text { Lana } \\
\text { Ferrara }\end{array}$ & $\begin{array}{l}\text { Grosoli } \\
\text { Ferrara }\end{array}$ & $\begin{array}{l}\text { Ungarelli } \\
\text { Ferrara }\end{array}$ & $\begin{array}{l}\text { Medini } \\
\text { Ferrara }\end{array}$ & $\begin{array}{l}\text { Barlaam } \\
\text { Ferrara }\end{array}$ & $\begin{array}{l}\text { Monti } \\
\text { Ferrara }\end{array}$ & $\begin{array}{l}\text { Tito } \\
\text { Minniti } \\
\text { Ferrara }\end{array}$ & $\begin{array}{l}\text { Due } \\
\text { Canali } \\
\text { Reggio } \\
\text { Emilia }\end{array}$ & $\begin{array}{l}\text { Maramotti } \\
\text { Reggio } \\
\text { Emilia }\end{array}$ & $\begin{array}{l}\text { Barca } \\
\text { Bologna }\end{array}$ \\
\hline $\begin{array}{l}\text { Photo } \\
\text { voltaic } \\
\text { installation } \\
\text { area }\left(\mathrm{m}^{2}\right)\end{array}$ & 550 & - & 215 & 170 & 420 & 68 & 450 & 134 & 175 & - \\
\hline $\begin{array}{l}\text { Installation } \\
\text { efficiency }\end{array}$ & $11.7 \%$ & - & $19.7 \%$ & $22.5 \%$ & $13.7 \%$ & $15 \%$ & & $17.3 \%$ & $13.5 \%$ & - \\
\hline $\begin{array}{l}\text { Installation } \\
\text { cost (Euro) }\end{array}$ & 200000 & - & 96000 & 58000 & 376200 & 27200 & 220000 & 48473 & 59000 & - \\
\hline $\begin{array}{l}\text { Estimate } \\
\text { energy } \\
\text { production } \\
\text { (Kwh/year) }\end{array}$ & 42500 & - & 26756 & 18216 & 62.700 & 8.260 & 62.000 & 23000 & 22936 & - \\
\hline $\begin{array}{l}\text { Yearly } \\
\text { profit } \\
\text { (Euro) }\end{array}$ & 9100 & - & 11773 & 7286 & 11286 & 9815 & 11160 & 4140 & 4200 & - \\
\hline $\begin{array}{l}\text { Payback } \\
\text { period } \\
\text { (year) }\end{array}$ & 12 & - & 9 & 8 & 11 & 9 & 12 & 12 & 8 & - \\
\hline
\end{tabular}

\subsection{Adding a greenhouse}

Adding a greenhouse was considered as a final intervention that can improve both architectural and energy efficiency of the building. A greenhouse is a glass structure that heats up because incoming visible solar radiation (for which the glass is transparent) from the sun is absorbed by floors, walls, and other materials inside of the building. This is a passive solar system in which air warmed by the heat from hot interior surfaces is retained in the building by the roof and wall. In addition, the warmed structures inside the greenhouse re-radiate some of their thermal energy in the infra-red, to which glass is partly opaque, so some of this energy is also trapped inside the glasshouse $[8,9]$. When orientation was considered as optimum (south, south-east façade) a greenhouse was added, or existent balconies were closed by glass panes. This intervention was considered in four case studies, that offered the best wall orientation for passive solar gain (Fig. 7). This intervention was supposed as a 'best practice' intervention in which the high initial investment cost can be justified with a global renovation of the image of the building (Fig. 8).

By considering that adding quality to architecture can improve not only technical aspects but also social aspects, such as quality of life and safety of inhabitants, it can be said that public administrations and housing company owners can take in consideration the possibility of having an overall improvement of the building, by reaching optimum levels of energy efficiency.

Finally, an evaluation of the passive solar benefits $\left(\mathrm{Kwh} / \mathrm{m}^{2}\right.$ saved by considering greenhouse effect in comparison to the same building without greenhouse) was estimated. As an example, in the case study shown below, via Medini building in Ferrara, the energy saving is $7234 \mathrm{kWh} / \mathrm{year}$, that 


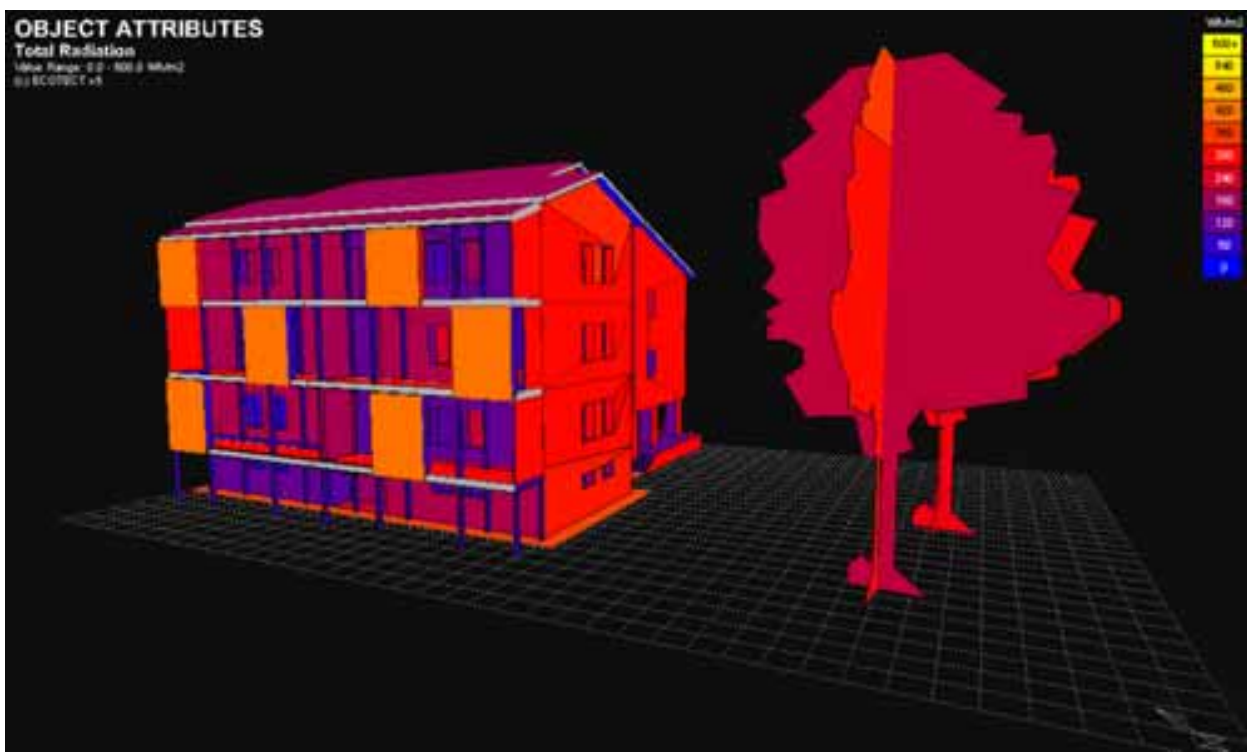

Figure 7: Solar irradiance on south-west front in via Medini building for adding a solar greenhouse.

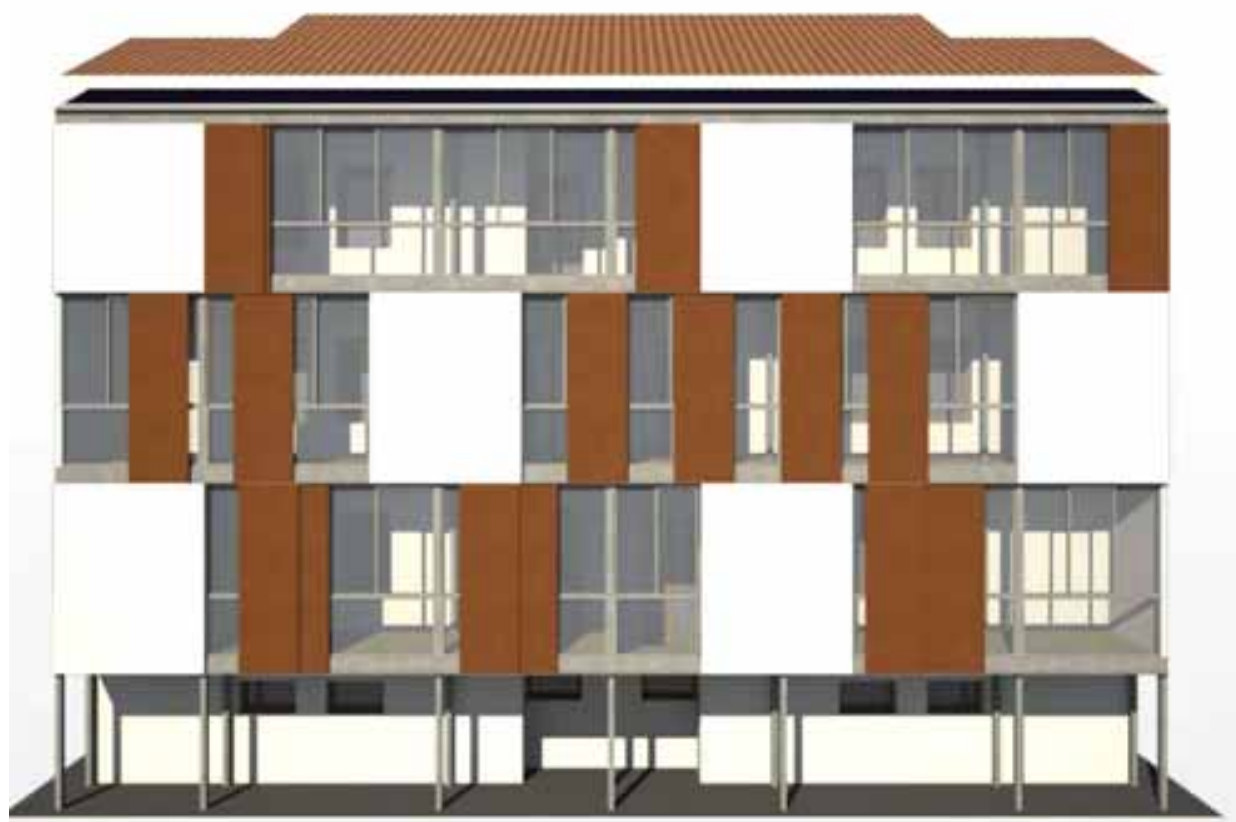

Figure 8: Design for a new front for via Medini building. The new solar greenhouse was designed both with opaque than glass panes. 
corresponds to $732.4 \mathrm{mc}$ of methane per year. This means about 590 Euro saved each year. In terms of energetic class $\left(\mathrm{kWh} / \mathrm{m}^{2}\right.$ year) it can be said that about $25 \mathrm{kWh} / \mathrm{m}^{2}$ year can be saved.

\section{CASE STUDY: TITO MINNITI BUILDING, FERRARA}

\subsection{Building description}

The case study described in detail regards the multi storey building block called Tito Minniti owned by the ACER Housing company of Emilia Romagna Region, build in 1935 and successively modified during the urban plan called 'PEEP' that included it in the quarter 'Foro Boario', one of the most famous suburb of Ferrara. Although popular origin, the area sees an increasing development in recent years due to the conversion of industrial areas and railway and adjacent to its proximity to the city centre. Looking at the context in which the building stands, you notice the low population density that characterizes the area that involves both the absence of shadow volumes due to adjacent and other dimensional relevance assumed by the building compared to the urban fabric.

This building, despite his humble origins, represents the architectural centerpiece of the area and therefore has not undergone substantial formal and structural manipulations, keeping almost unchanged the morphological, volumetric and stylistic choices (Fig. 9).

The building is four floor high: all floors are residential, except the ground floor where there are also technical rooms. Apartments have both north-south and east-west view, depending on the location. There are three typologies of apartment: two, three and four rooms, of various sizes. The attic generated by double pitch roof is not a living space but only accessible for maintenance.

Walls are load bearing brickwork [two layers $(25 \mathrm{~cm})$ and in some portions three layers $(38 \mathrm{~cm})$ ]. Ground floor is reinforced concrete slab, with loose stone foundation. Intermediate floors are concrete

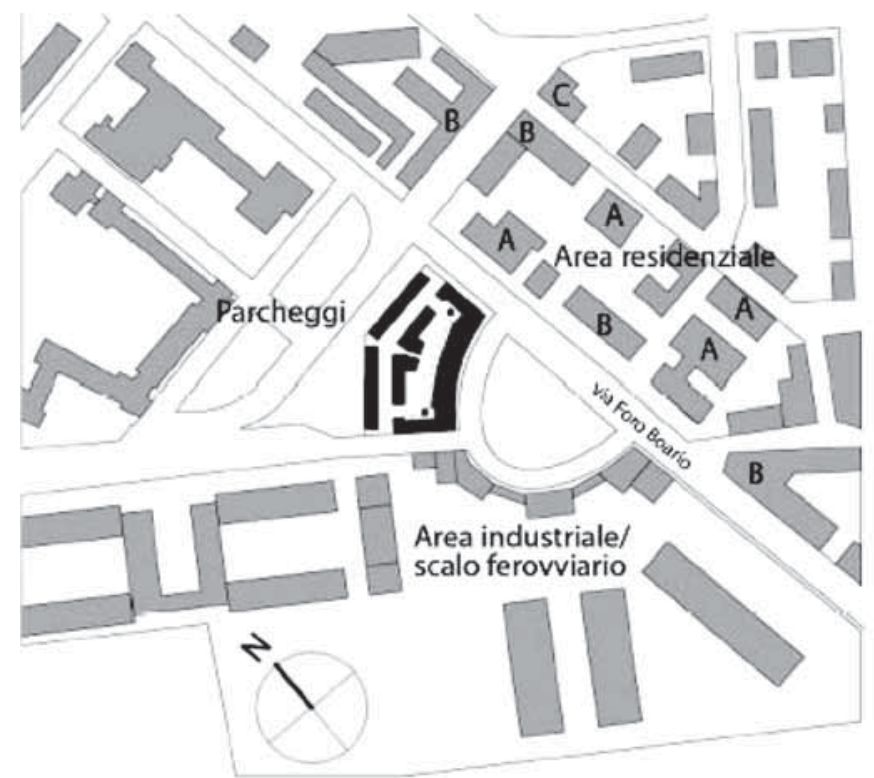

Figure 9: Plan of the area. Residential Area: A residential buildings.2 floors B. Building block 4 floors $\mathrm{C}$. Tower buildings 5 floors. 

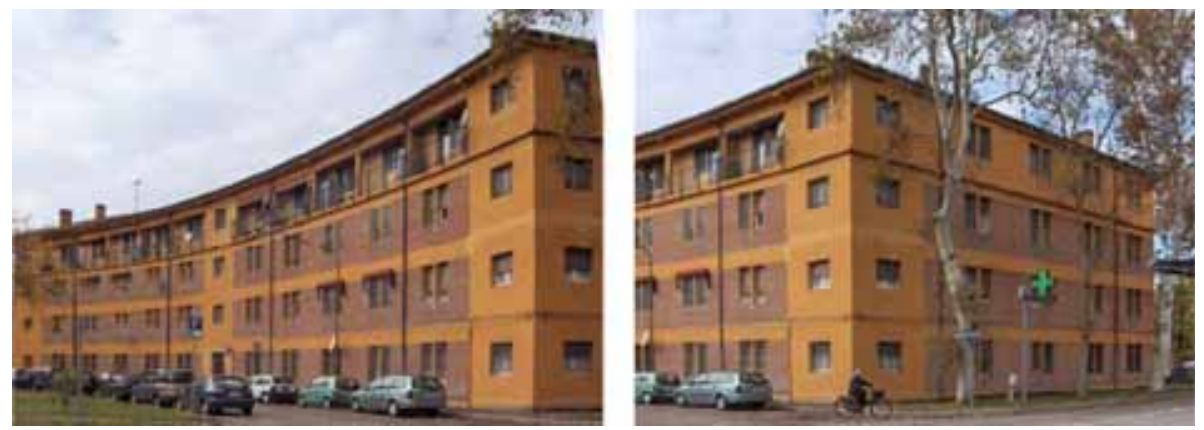

Figure 10: Main front on Foro Boario street.

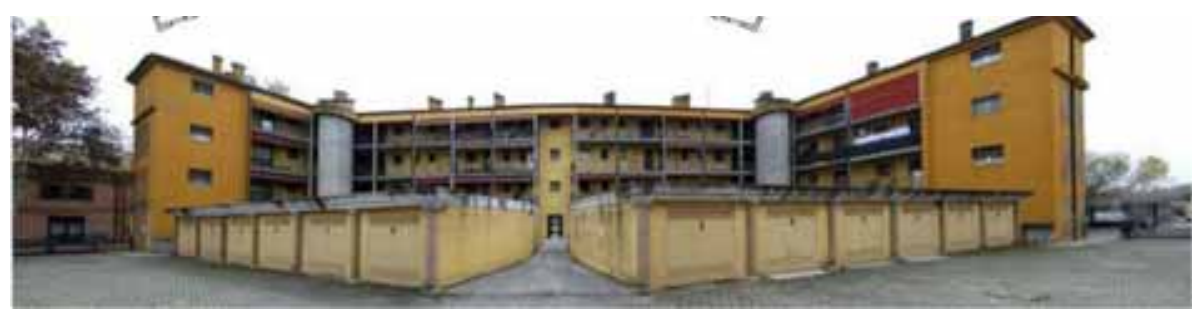

Figure 11: Back front on the courtyard.

pre straightened beams with filling brick blocks. No insulation is present except for the last floor that divides the apartment from the attic. Windows are single layer with wooden frames (Figs. 10 and 11).

Heating system is autonomous for each apartment. It consist on a heat generator of ' 90 with an on/ off thermostat in the living room. Cast iron radiators, without regulations valve, are mainly located under windows.

Energy efficiency of the building was calculated by considering winter energy balance comprehensive of domestic hot water production, by the use of energy software calculation MC 11300 . The energy balance was of $186 \mathrm{Kwh} \mathrm{m}^{2}$ a that corresponds to an F energetic class, so a poor result in terms of energy efficiency, that needs to be improved.

\subsection{Strategies of intervention}

For the refurbishment and upgrading of the building the following action were considered:

1. Rockwool external thermal insulation, to comply with current energy efficiency standards on external walls $\left(\mathrm{U}=0.34 \mathrm{Wm}^{2} \mathrm{~K}\right)$;

2. Roof insulation to comply with current energy efficiency standards $\left(\mathrm{U}=0.30 \mathrm{Wm}^{2} \mathrm{~K}\right)$;

3. Windows replacement with more efficient windows $\left(\mathrm{Uw}=1.3 \mathrm{Wm}^{2} \mathrm{~K}\right)$;

4. Conversion from single heat generators to centralized heating system (optimization of the heating energy);

5. Renewable energy integration: solar collector for domestic hot water production and PV panels for electric consumptions. 
External thermal insulation was planned in $12 \mathrm{~cm}$ of rock wool panels (Fig. 12). This material, in comparison to a standard insulation in polystyrene, can offer better performances: first of all it is a natural material, at the same time it has an optimum value of thermal conductivity $\left(0.036 \mathrm{Wm}^{2} \mathrm{~K}\right)$, an optimum value of vapour permeability ( $\mu=8$, to avoid condensation phenomenon in winter season), a good density $\left(90 \mathrm{Kg} / \mathrm{m}^{3}\right)$ that helps in mass heat storage (thermal phase displacement, mitigation factor) and last but not least an acceptable cost of construction, that is not so different from the most economic synthetic polystyrene ETICS.

Envelope performance is improved from an initial value of 1.45 to $0.28 \mathrm{Wm}^{2} \mathrm{~K}$. The cost of the operation was evaluated in 70 Euro per square meter, for an overall cost of 180.000 Euro.

To complete the envelope improvement, a thermal insulation layer was hypothesized in the roof floor. This kind of intervention seems to be the most suitable when a not liveable attic is present, as it allows to insulate directly on the cold side in correspondence of the living units (global thermal transmittance optimization).

Global envelope insulation (walls plus roof floor) can provide an improvement of the energy balance of $80 \mathrm{KWh} \mathrm{\textrm {m } ^ { 2 }}$ a with a jump from $\mathrm{F}$ class to D class. By considering the investment cost of the intervention (150.000 Euro) and the yearly gas methane cubic meter saved by the energy efficiency improvement ( $1 \mathrm{mc}$ of methane corresponds to $10.78 \mathrm{kWh}$ ) of $12.500 \mathrm{mc}$, it can be said that the payback period of this operations should be of 15 years (considering methane cost of $0.83 \mathrm{Euro} / \mathrm{mc})$.

The third improvement action was the replacement of old windows, that were single layer wooden frames and represent a considerable energy failure in the overall energy balance of the building, due to their percentage in relation to the opaque wall. Double layer low-e glass panes 4-15-4 Argon gas filled in with wood/steel frame were considered, for a total $\mathrm{U}$ windows value of $1.3 \mathrm{Wm}^{2} \mathrm{~K}$.

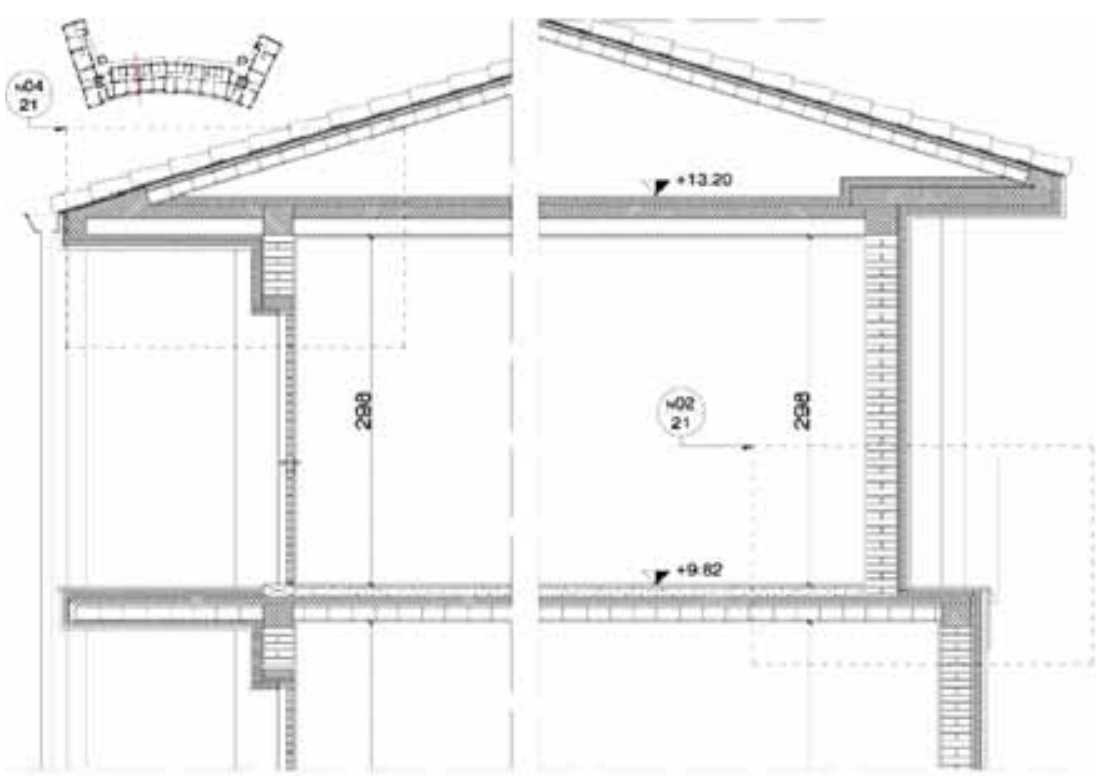

Figure 12: Vertical section. External thermal insulation coatings in rockwool panels for the global thermal transmittance improvement (U value) and thermal bridges correction. 


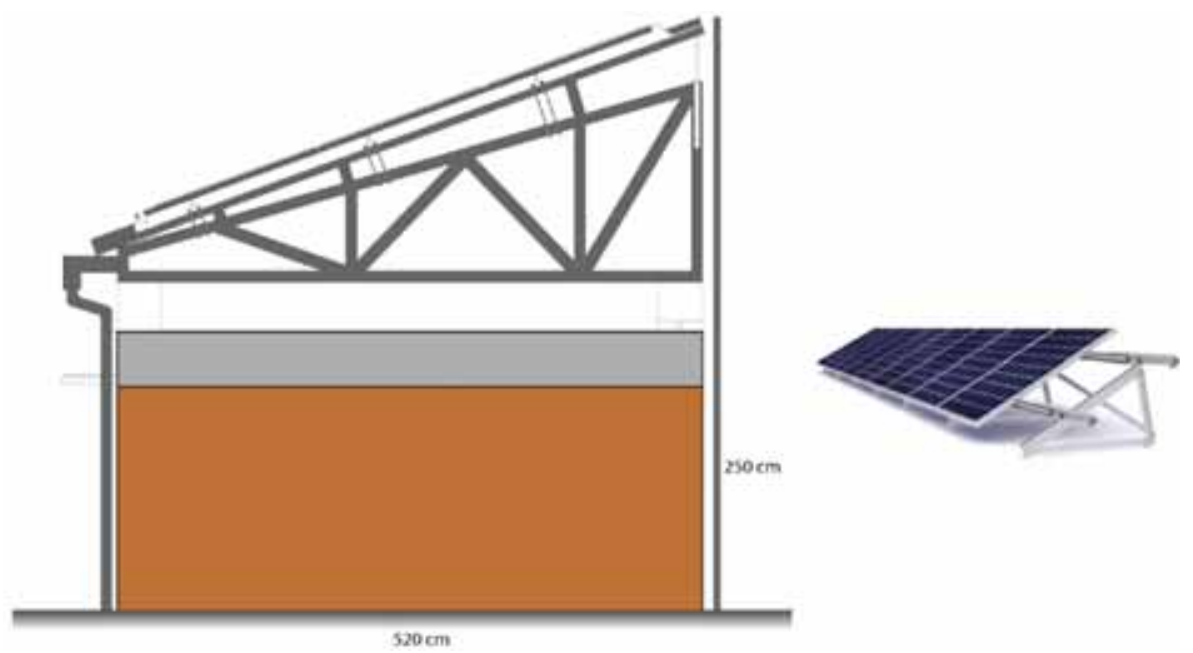

Figure 13: Photovoltaic installation on self bearing stainless steel structure on building and garages roof.

Against the high costs (about 135.000 Euro), this operation can provide high energy saving results, due to the high percentage of glass surface in comparison to massive wall, mainly in the west and east faces, that leads to a jump from $\mathrm{D}$ to $\mathrm{C}$ class.

In order to optimize the heating system, the conversion from autonomous generators to a centralized condensation boiler was planned. This solution can improve plant yearly efficiency performance from $86 \%$ to $98 \%$ (about the total energy use). A better result can be reached by considering also radiators replacement in the apartments, that can improve the emission performance. In this phase this operation was not considered due to the high grade of incidence of building operation in comparison to inhabitants comfort and possibility to stay in their homes, moreover to avoid additional cost for people transfer in satellite dwellings.

In the following step, the contribution of renewable energy was considered. It was planned to install solar collector for domestic hot water and PV panels on the portion of flat roof and in the garages roof (Fig. 13). 224 mono crystalline panels with a peak power of $250 \mathrm{~W}$ set on stainless steel structures with a tilt angle of 32 degrees. The overall cost for this operation can be valued in 220.000 Euro.

With the contribution of renewable energies, global energy balance can be valued in $39 \mathrm{Kwh} \mathrm{\textrm {m } ^ { 2 }}$ a (A class), with a total energy of 84.499.35 Kwh per year. This can provide an energy saving of $7835 \mathrm{mc}$ of gas methane per year that corresponds to 19.616 Euro per year saved. As the global cost of the intervention was calculated in 635.000 Euro, it can be said that the payback period, by considering also the 'Conto Energia' incentives, is about 19 years so it can be evaluated as convenient.

\section{CONCLUSIONS}

Post war building stock sector account for the most energy loss waste on earth, owing to the low thermal insulation level of the envelopes, high thermal dispersions and minimum exploitation of the climatic resources.

Like in many other Countries in Europe, in Italy the large housing shortages resulting from World War II have been resolved by constructing large quantities of multifamily housing with a poor 
technical and functional performance. One of the most important goal for 2020, following the new European Directive (31/2010/UE) is the reduction of about $20 \%$ of global emissions and the use of renewable energies in the measure of $20 \%$. This puts in a first level the intervention on building sector and mostly in the buildings that, for their dimensions and their poor quality, represent a big failure in the global environmental balance.

High performing envelopes and renewable energies are the most useful strategies to improve not only the energetic balance, but also the architectural value of these buildings.

To reach the best results, it is essential to integrate all the factors influencing urban building envelopes and look at it in a broader scope. This requires the development of new and suitable strategies for local authorities, housing corporations and owners on one hand, and for architects and civil engineers on the other hand, involving a multitude of factors such as: quantitative technical demands, qualitative aspects, and environmental aspects, including energy use.

Guidelines for an energy retrofit action planning, deducted by this study, can be summarized as follows:

1. The most easy and immediate action that can improve energy performance of a building is the intervention on installations. Energy efficiency can be as much improved as generators are substituted with more efficient ones. In case of single - apartment boilers, the replacement of old generators with new ones (condensation boilers) can improve energy efficiency of about 15\%, this mean less money for the investment, but also less energy efficiency. This kind of intervention can be taken in consideration in the case of very low initial budget, when no other solution is possible. Anyway, current tendencies shown how the maximum grade of efficiency can be obtained with plants centralization. The advantage of centralized systems is that with one generator you can heat an entire building, this can improve production and emission outputs. Energy performance will be better if in any apartment a heat counter is installed, as each user can pay and regulate his own requests. This kind of intervention is more convenient when high-efficiency systems are used (e.g. heat pump, co-generation systems, fuel cells) and, in this case, an improvement of the thermal transmittance of envelope is needed. The step from single apartment to centralized systems has to be carefully evaluated on a case by case basis, as it is very difficult to give general indications. Anyway, as this can not be consider a 'best price' step, as the initial investment will be refund as shortly as the efficiency of the new generator is better.

2. Adding solar collectors for domestic hot water production and heating system integration is quite economic and can be realized without big modifies (heat water storage needs a separate room but generally attic rooms are used), in compliance with single boilers. Medium cost of a solar collector installation ranges from 1500 to 2000 Euro for a four-people family. This solution can offer a considerable energy saving, mainly considering domestic hot water production. In comparison to other European countries, it seems that Italy does not properly take benefit of this solution, by considering that the medium solar incidence is $1.500 \mathrm{kWh}$ per square meter per year: this value is similar to Greece's one, but greater than Denmark and Germany's one, where the use of solar energy is very popular. If we consider a medium performance of about 160.000 solar collectors installed in any Italian region, it can be said that about 8 million of cubic meters of gas methane for domestic hot water heating will be saved. Adding solar collectors on roof should be a good cost-benefit action, when roofs have the correct orientation (south, southeast, southwest), and it can be considered as one of the first action to undertake in the energy retrofit planning.

3. The use of PV panels for electricity production can offer a good opportunity to reduce electric consumption: a medium family domestic consumption for electrical equipment is $3 \mathrm{~kW}$, that 
corresponds to $4000 \mathrm{kWh}$ for an annual expenditure of 600-700 Euro. To fulfill this requirement about 15-20 square meters of south-oriented PV installation are required, for a global expenditure of about 8.000 Euro. Taking advantage from the Conto Energia incentives, a PV installation that produces about $4000 \mathrm{kWh}$ per year can earn about 1.200 Euro for grid connected tariff and about 600 Euro for on-site power exchange tariff for an annual profit of 1.800 Euro. Pay back period of this intervention is estimated in 6.5 years, where annual rates are completely covered by Conto Energia incentives. Electric gain by PV systems is much more effective as apartments are electric - heated and not gas-heated (e.g. electric heat pump supplied by PV system): in this case not only electrical expenditures are reduced but also heating consumptions can be repaid. In any case, this kind of intervention maximizes cost-benefits and can be considered as one of the most convenient intervention.

4. The energy balance through the envelope (called 'thermal energy', as UNITS 11300 - Part 1 regulation prescribes) represents more than the $60 \%$ of the overall energy balance (EPi) and it is made by four main factors that, in higher or smaller measure, weight on the calculation: thermal transmittance (incidence is about $38 \%$ ), ventilation losses (25\%), solar gains (20\%), internal gains $(17 \%)$. By considering this percentage, it can be said that the wall thermal insulation improvement is the most effective action to undertake in order to reduce heating requirements. As thermal transmittance of walls is lower, as it will be possible to reduce installation power and, consequently, the energy consumptions. In the case of Emilia Romagna regulation standards, the global thermal transmittance of walls can be reduced of about one third by using $12 \mathrm{~cm}$ of thermal insulation, this means an average of $120 \mathrm{kWh} \mathrm{m} /$ year saved, with a jump from G-F class to D class. ETICS realization cost is not properly economic, as its ranges from 70 to 90 Euro per square meter. This means a substantial initial cost that can be refund in about 10 years or more, if no modifications on the plants are done. This period can be reduced if the intervention comprehends also heat generator substitution and/or PV installation.

5. At the same time, the cost - benefits evaluation for windows replacement is remarkable in the case of big number of windows and, consequently, high thermal losses from glass surface. Replacing windows with more efficient ones requires, in the most cases, some interventions on walls and jambs that may have no sense when thermal insulation in walls remains lacking. For this reason a global intervention it should be desirable, as initial costs should be amortized with a better energy performance. In the case that ETICS insulation could be not realized, a double window would be more convenient. Overlapping a second window in front of the existent one is more economic than replacing it, and can offer good performance as it works like a double/ triple pane glass.

6. Adding a solar greenhouse features an energy saving mainly due to higher thermal insulation of the building envelope, reducing heat losses and improving the contribution of thermal energy from the sun, even if it is quite difficult to calculate the effective quantity of energy gained. Main benefits are due to the thermal radiation gathered into the greenhouse and transferred to the apartment, the reduction of heat loss due to the hot air inside the greenhouse and the preheating of the air flowing from the greenhouse to the building. During the heating period, the energy contribution of the examined solar greenhouses corresponds to a supply free energy in the order of 30-35\% of the global requirement. This can be considered as a cost-benefit good result when greenhouses are obtained by closing existing balconies in south, south-east or south west oriented façades. Adding a greenhouse as a new volume, especially when we speak of big volumes, may require initial costs too high in relation to the effective energy saving, although this expenditures can be amortized if the greenhouse roof supports PV panels. 
7. Finally, the payback period of energy measures can be considerably reduced by considering the fiscal facilitation of 55\% subtraction that is in force in Italy until June 2013 (expected it will be extended also in 2014 but it depends on new government). This facilitation allows to deduct from annual taxation of each citizen the amount of $55 \%$ of the expenditures for refurbishment actions in order to improve energy efficiency interventions in buildings, divided in maximum 10 yearly rates for an overall amount of 100.000 Euro. This was not included in the pay back period calculation, as it not sure that this opportunity will be given also in the future, but it has to be taken in account as it can reduce the payback period of a half.

By considering that housing companies and public administrations carefully evaluates costs and benefits before starting refurbishment interventions, this study can help in determining the advantages of up-to-date technologies in the enhancement of the energetic performance of buildings.

A limit of the study regards the energy performance calculation. According to the current energy efficiency law in Italy, the complete calculation of the Global Energy performance (EPi) in his complete formulation should comprehend, besides heating and hot water supply, also the energy balance in summer season (e.g. cooling, thermal inertia) and the electricity consumptions. The calculation of the last two terms is defined by the technical methodology UNITS 11300 - Parts 3 and 4 that have been issued since few months and have not been adopted yet. This means that it is not available at now an energy calculation software that estimates the energy performance in summer season by following the new calculation method defined by technical law UNITS11300 3 and 4.

One of the future development of the work should be, as soon as it will be possible, to insert the second part of the energy calculation procedure, including also summer season energy performance and, consequently, evaluate properly refurbishment action to improve summer requirements (e.g. ventilated façades, solar shadings).

\section{REFERENCES}

[1] AA.VV., Energetic Control of Buildings course, University of Ferrara, Department of Architecture, Thesis on energy assessment and retrofit hypothesis of ACER building stock in Emilia Romagna region, Academic years 2007-2012.

[2] Brunoro, S., Efficienza energetica delle facciate. Standard, requisiti, esempi per l'adeguamento e per la riqualificazione architettonica. Maggioli: S. Arcangelo di Romagna, pp. 28-35, 2006.

[3] Brunoro, S., "Technical improvement of housing envelope in Italy. Improving the Quality of Existing Urban Building Envelopes, eds. L. Bragança, C. Wetzel \& L.G.W. Verohef, IOS Press: Amsterdam, pp. 69-82, 2007.

[4] Aste, N., Il fotovoltaico in architettura - l'integrazione dei sistemi a energia solare negli edifici. Esselibri: Napoli, 2005.

[5] WIT Transactions on Ecology and The Environment, Vol. 165, (C2012 WIT Press, available at www.witpress.com, ISSN 1743-3541 (on-line) doi: 10.2495/ARC120271. doi: http://dx.doi. org/10.2495/ARC120271

[6] Brunoro, S., An assessment of energetic efficiency improvement of existing building envelopes in Italy. Management of Environmental Quality. An International Journal, 19(6), pp. 718-730, 2008.

[7] AA.VV., Photovoltaics. Technology, Architecture, Installation, Birckhauser: Basel, 2010.

[8] McCullagh, J.C., The Solar Greenhouse Book, Rodale Press: Emmaus, 1978.

[9] Compagno, A., Intelligent Glass Facades, Birkhauser: Berlin, 1999. 